\title{
Modeling dietary influences on offspring metabolic programming in Drosophila melanogaster
}

\author{
Rita T Brookheart and Jennifer G Duncan \\ Department of Pediatrics, Washington University School of Medicine, St Louis, MO, USA \\ Correspondence should be addressed to J G Duncan; Email: duncan_j@wustl.edu
}

\begin{abstract}
The influence of nutrition on offspring metabolism has become a hot topic in recent years owing to the growing prevalence of maternal and childhood obesity. Studies in mammals have identified several factors correlating with parental and early offspring dietary influences on progeny health; however, the molecular mechanisms that underlie these factors remain undiscovered.

Mammalian metabolic tissues and pathways are heavily conserved in Drosophila melanogaster, making the fly an invaluable genetic model organism for studying metabolism. In this review, we discuss the metabolic similarities between mammals and Drosophila and present evidence supporting its use as an emerging model of metabolic programming.

Reproduction (2016) 152 R79-R90
\end{abstract}

\section{Introduction}

The environmental impact during in utero and childhood development on adult health has recently emerged as a hot topic due to the increased prevalence of obesity in childhood and adolescence and the fact that 25-30\% of pregnant women in the United States are obese, both of which place offspring at an increased risk for developing major health complications $\left(\mathrm{O}^{\prime}\right.$ Brien et al. 2003, Freedman et al. 2005, 2009, Dokras et al. 2006, Metwally et al. 2008, Catalano et al. 2009, Clausen et al. 2009, Nohr et al. 2009, Stothard et al. 2009, Vahratian 2009, Biro \& Wien 2010, Lowe et al. 2011, Forno et al. 2014, Diesel et al. 2015). Barker introduced the concept that maternal malnourishment as well as altered infant nutrition can permanently influence offspring metabolism and predispose progeny to cardiovascular and metabolic diseases (Barker 1990, Hales \& Barker 1992). Additional studies have also demonstrated strong correlations between the malnourished parent and compromised offspring health (Stanner et al. 1997, Ravelli et al. 1998, Kaati et al. 2002, Painter et al. 2005, Pembrey et al. 2006). Substantial evidence from both human and animal models has implicated several factors including altered epigenetic gene regulation, ER stress, and mitochondrial disruption as vehicles through which parental diet impacts offspring development and health (Gemma et al. 2006, 2009, Bruce et al. 2009, Carone et al. 2010, Igosheva et al. 2010, Ng et al. 2010, Vucetic et al. 2010, Wu et al. 2010, 2015, Borengasser et al. 2011, Luzzo et al. 2012, Herbstman et al. 2013, Soubry et al. 2013, Malti et al. 2014, Melo et al. 2014, Radford et al. 2014, Gallardo et al. 2015, Casas-Agustench et al. 2015, Sharp et al. 2015). However, to date, the molecular mechanisms by which altered nutrition influences these factors to impact offspring health are not entirely clear.

Recently, Drosophila melanogaster has emerged as a promising tool to uncover the molecular mechanisms of metabolic programming. In the fly, the impact of parental diet on offspring health can be determined by altering the maternal or paternal diet, or both. Because fly embryogenesis occurs outside of the maternal female, scientists can also investigate the influence of the pregestational maternal diet on offspring nutritional programming without the highly invasive procedures of in vitro fertilization and intracytoplasmic sperm injection required of mammalian studies (Ceelen et al. 2007, 2008, Giritharan et al. 2007, Scott et al. 2010, Wu et al. 2015). Moreover, understanding the impact of nutrition during early development on adult health within a single generation can be modeled in the holometabolous fly by manipulating the larval diet and assessing changes in adulthood. Use of the fly in nutritional programming is attractive for several additional reasons including the ease by which laboratories can economically design and produce customized diets, the high conservation of metabolic pathways in Drosophila, and the already extensive use of the fly in metabolic and developmental research. Also, because one of the main questions regarding metabolic programming is the impact it has on subsequent generations, the rapid fly life cycle, 10 days from embryo to adult, provides a further benefit for using Drosophila to understand the molecular mechanisms of the transgenerational impact of the parental diet. This review focuses on the benefits of using Drosophila to understand human metabolism and the emergence of 
the fly as a tool to model the impact of parental and early offspring nutrition on metabolic programming.

\section{Benefits of the Drosophila model in metabolic studies}

\section{Genetics and dietary manipulation}

Mammalian models have been successful in identifying several factors that may contribute to metabolic programming; however, many of these observations remain correlative. Recently, Drosophila melanogaster has proven a powerful tool in uncovering the molecular mechanisms involved in several human metabolic diseases - in fact, an average of $75 \%$ of the known human disease-related genes are conserved in the fly (Reiter et al. 2001, Sanchez-Martinez et al. 2006, Baker \& Thummel 2007, Fernández-Moreno et al. 2007, Birse et al. 2010, Musselman et al. 2011, $\mathrm{Na}$ et al. 2013). Methods exist in the fly for the analysis of metabolic profiles including measurement of circulating and stored lipids and carbohydrates and ATP levels as well as tools for metabolomics (Tennessen et al. 2014).

Much of the interest in Drosophila is due to the exceptionally well-developed genetic tools allowing for the rapid generation of whole-body, tissue-specific, and/or developmental stage-specific gene-manipulated strains as well as the development of sophisticated genetic screens (del Valle Rodríguez et al. 2012). Drosophila offers enormous transgenic libraries, some covering up to $91 \%$ of the fly protein-coding genome and include over 26,000 RNAi lines and a plethora of overexpression strains, enabling researchers to investigate various mutant versions of a single gene (Dietzl et al. 2007, Vienna Drosophila RNAi Center 2015). Specific gene mutants that are not commercially available can be quickly and relatively easily generated using either the classic method of transposon-mediated mutagenesis or the new approach of CRISPR genome editing (Bassett et al. 2013). Several groups have taken advantage of the sophistication and ease of fly genetics to identify novel metabolic regulators (Beller et al. 2008, Guo et al. 2008, Jumbo-Lucioni et al. 2010, Pospisilik et al. 2010, Baumbach et al. 2014). One such study used large-scale RNAi to knockdown $49 \%$ of protein-coding Drosophila genes in the fat body and portions of the midgut and identified 77 genes that altered organismal fat content, $83 \%$ of which have a human ortholog (Baumbach et al. 2014). One of the conserved genes, a component of the store-operated calcium entry core, was identified as a novel regulator of adiposity (Baumbach et al. 2014). Another group performed a Drosophila genome-wide obesity screen, targeting 10,489 open reading frames with 11,594 transgenic RNAi fly lines to identify genes involved in fly adiposity (Pospisilik et al. 2010). From their screen, Pospisilik and coworkers identified 500 candidate regulators of fly triglyceride levels, including genes involved in feeding behavior and key lipid regulators such as fatty-acid synthetase and Drosophila homologs to PI3K and the insulin receptor. Interestingly, this screen revealed a previously unknown role for Hedgehog signaling in fat body adiposity and identified the Hedgehog pathway as a determinate of mammalian adipocyte cell fate (Pospisilik et al. 2010).

Dietary manipulations in the fly are relatively easy, economical, and the variations in diet are limitless primarily due to the fact that most diets can be produced in the laboratory. Moreover, several methods exist to quantify food ingestion (Deshpande et al. 2014, Tennessen et al. 2014). The concentrations and types of lipids, carbohydrates, amino acids, and other ingredients can be easily and quickly adjusted or omitted from fly diets to test the contribution of specific nutrients to metabolic programming. Specific compounds and pharmaceuticals can also be added to fly diets to either assess their therapeutic potential or as a method of inhibiting or activating a particular signaling pathway (Kang et al. 2002, Agrawal et al. 2005). Taking advantage of these benefits, many studies have used Drosophila to investigate the mechanisms involved in dietary restriction and overnutrition (previously reviewed by Tatar et al. 2014).

Overnutrition in the form of excess fat and sucrose in Drosophila mimics the pathophysiology of mammalian obesity including insulin resistance, hyperglycemia, nonadipose lipid accumulation, cardiomyopathy, shortened lifespan, and elevated expression of lipogenic and gluconeogenic genes (Birse et al. 2010, Musselman et al. 2011, 2013, Pasco \& Leopold 2012, Na et al. 2013). Using these models of overnutrition, several studies identified new roles for classic metabolic pathways in obesity-related human diseases including insulin-TOR pathway, SREBP, PGRC1, retinol-binding protein 4, and the hexosamine biosynthetic pathway (Birse et al. 2010, Pasco \& Leopold 2012, Na et al. 2013, Diop et al. 2015). Such studies underscore the many benefits of using the fly to uncover new functions for known genes as well as to identify novel genes related to human metabolic disease.

\section{Metabolic tissue and pathway conservation}

Midgut - nutrient absorption

There exist many similarities between the mammalian and fly digestive systems (Apidianakis \& Rahme 2011) (Fig. 1). The pharynx, esophagus, and crop (analogous to the stomach) comprise the fly foregut, one of three sections of the Drosophila gut. The hindgut follows the midgut and is the site of water absorption. While nutrient absorption and digestion occur in the mammalian stomach and small intestines, in the fly, these activities are primarily restricted to the midgut. The gut is also the site of lipid absorption, whereby dietary TAG is metabolized most notably by a homolog of mammalian gastric 


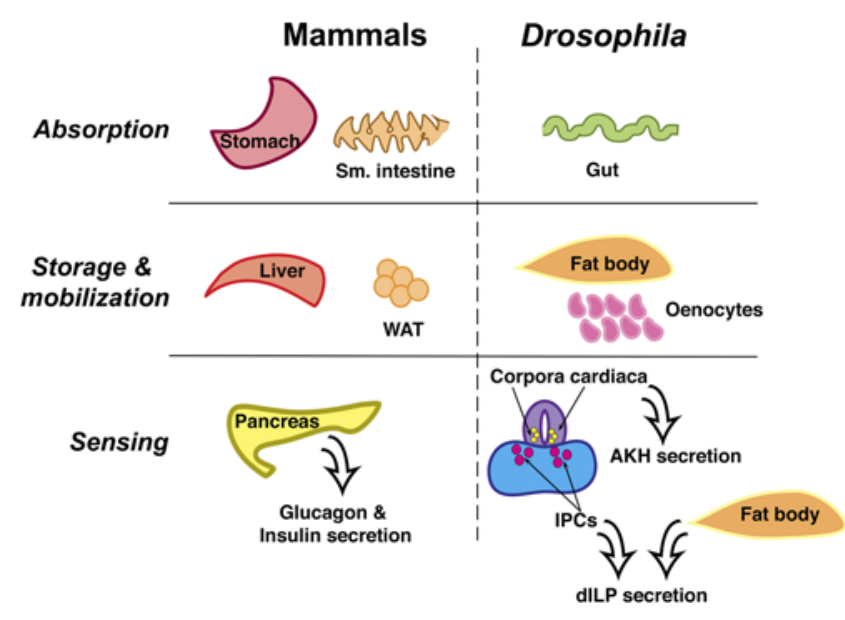

Figure 1 Conservation of metabolic tissues in Drosophila. Nutrient absorption and digestion in mammals primarily occurs in the stomach and small intestine. Drosophila contains a three-sectioned gut (foregut, midgut, and hindgut) in which the midgut performs the bulk of these functions. The fly malpighian tubules at the junction of the midgut and hindgut perform functions similar to the mammalian kidney. Storage and mobilization of carbohydrates and lipids occurs in the fat body and is analogous to mammalian white adipose tissue (WAT) and the liver. Oenocytes also play a key role in lipid storage and mobilization. The action of glucagon in response to decreased glucose levels mirrors that of the fly adipokinetic hormone $(\mathrm{AKH})$, while, like insulin, Drosophila insulin-like peptides (dILPs) respond to increased nutrient availability. AKH is also known to act similarly to mammalian $\beta_{3}$ agonist and induce mobilization of TAG from lipid droplets.

lipase, Magro, into monoacylglycerides and fatty acids, which can then be absorbed by enterocytes, converted to diacylglycerides, and transported in the hemolymph as lipoproteins (Sieber \& Thummel 2009). Malpighian tubules are at the junction of the midgut and hindgut and perform functions analogous to mammalian kidneys.

\section{Fat body - nutrient storage, mobilization, and sensing}

Nutrients absorbed by the midgut are circulated through the hemolymph, the Drosophila equivalent of mammalian blood, and delivered to the fat body. The fat body is analogous to the liver and white adipose tissue and is the site of lipid and carbohydrate storage and mobilization and de novo lipogenesis (Dobrosotskaya et al. 2002, Seegmiller et al. 2002, Liu \& Huang 2013). Lipids reach the fat body in the form of lipoproteins, with lipophorin being the most abundant type (Kutty et al. 1996, Arrese et al. 2001, Palm et al. 2012). Lipophorins are taken up by the fat body via the lipophorin receptor, a member of the LDL receptor family, and converted to TAG and stored in lipid droplets (Arrese \& Soulages 2010). Dietary sugars are metabolized in the midgut and transferred to the fat body for storage in the form of glycogen. A fairly recent discovery identified larval oenocytes as Drosophila hepatocyte counterparts, expressing many genes homologous to mammalian lipid metabolic genes, as well as serving a key role in lipid droplet storage and fatty acid utilization (Gutierrez et al. 2007).

In addition to nutrient storage, the fat body is also a site of lipid and carbohydrate mobilization. During times of nutrient deprivation or increased energy expenditure, the fat body synthesizes trehalose from glycogen stores for release into the hemolymph for subsequent use by other tissues. Mobilization of fat body lipid droplets requires the hydrolysis of TAG to DAG by the specialized lipase Brummer, a homolog of human adipose triglyceride lipase (Grönke et al. 2005). As in mammals, specific signaling events regulate nutrient mobilization in Drosophila and are discussed in further detail.

The fat body also functions as a nutrient sensor in the control of organismal growth. Studies have shown that modulating components specifically in the fat body of the insulin/insulin-like growth factor and TSC/ TOR pathways, both highly conserved in the fly, alter organismal size. Inhibiting activation of the insulin receptor $(\operatorname{InR}) / \mathrm{PI} 3 \mathrm{~K}$ pathway through fat body-specific expression of a dominant negative p60 produces developmentally arrested larvae with proportionately small organs; on the other hand, promotion of insulin signaling by either inducing fat body-specific expression of the insulin-like peptide dILP6 or targeting the PI3K inhibitor u-shaped (USH) through fat body-expressed microRNA mir-8 increases growth of both fat body cells and the organism (Britton et al. 2002, Hyun et al. 2009, Okamoto et al. 2009, Slaidina et al. 2009). As in mammals, Drosophila TOR (dTOR) can be activated by both the InR/PI3K pathway and extracellular nutrient availability to control cellular growth (Oldham et al. 2000, Zhang et al. 2000). Depletion of the amino acid transporter slimfast in the fat body produces developmentally delayed and smaller larvae relative to control animals that die during the pupal stage (Colombani etal. 2003). When a milder RNAi knockdown condition was used, slimfast-depleted larvae developed beyond the pupal stage, producing adults that were over $50 \%$ smaller than control flies (Colombani et al. 2003). Interestingly, the growth defect in the slimfast mutant was partially rescued by expression of the dTOR downstream target 66 Kinase and larvae expressing dominant-negative dTOR in the fat body phenotypically resembled slimfast knockdown animals (Colombani et al. 2003). Depletion of slimfast in the fat body also inhibited dILP2 release from IPCs and systemically suppressed the InR/PI3K pathway (Colombani et al. 2003, Géminard et al. 2009). This failure to secrete dILP2 in response to suppressing amino acid import in the fat body was also observed in dietary-restricted animals when dTOR signaling was disrupted, indicating that notification of amino acid availability is relayed from the fat body to the brain by dTOR (Géminard et al. 2009).

The nutrient-sensing capabilities of the fat body are also modulated by the steroid hormone ecdysone. Suppressing ecdysone signaling in the fat body by 
targeting the ecdysone receptor (EcR) produced larger larvae and pupae compared with control animals (Colombani et al. 2005). Two distinct mechanisms by which ecdysone may control organismal size have been reported. One study demonstrated that fat body knockdown of EcR increases dMyc expression causing a decrease in both fat cell ribosomal number and overall animal size (Delanoue et al. 2010). However, it was also shown that overexpressing $\mathrm{dMyc}$ in the fat body increases larval size (Delanoue et al. 2010, Parisi et al. 2013). Another report showed, using fat body EcR knockdown and a dominant-negative EcR, that ecdysone controls organismal size by inhibiting expression miR-8 in the fat body, which leads to increased USH activity and blunted organismal growth (Jin et al. 2012).

\section{Conservatiown of nutrient pathways}

Several signaling pathways that control the sensing and utilization of carbohydrates, lipids, and amino acids are highly conserved in the fly. In the pancreas, $\alpha$ - and $\beta$-cells control blood glucose levels through the balanced secretion of glucagon and insulin, respectively, and are secreted at low levels in the basal nonfasting state (Campbell \& Drucker 2015). In the fly, there are three tissues that regulate glucose levels, the corpora cardiaca, the IPCs in the brain, and the fat body. The ring gland houses the neurosecretory cells of the corpora cardiaca, which, like pancreatic $\alpha$-cells, secrete the glucagon-like protein adipokinetic hormone (AKH) (Kim \& Rulifson 2004). Like glucagon, AKH is derived from the processing of a preprohormone and in its mature form binds to the AKH G-protein-coupled transmembrane receptor located on the plasma membrane of fat body cells (Rayne \& O'Shea 1994, Noyes et al. 1995, Staubli et al. 2002). AKH receptor binding promotes glycogenolysis, the synthesis and subsequent release of trehalose, the major circulating sugar in the fly, and lipolysis (Staubli et al. 2002, Van der Horst 2003, Rhea et al. 2010).

Another highly conserved gene in the regulation of carbohydrate metabolism is the Drosophila ChREBP homolog Mlx interactor (Mio/Mondo), which is activated in response to increased glucose and induces expression of genes involved in lipid biosynthesis and glycolysis, and as such, its promotion of lipogenesis is required for survival on an obesogenic high-sucrose diet (Postic et al. 2007, Musselman et al. 2013). Recently, it has been reported that, in the brain, Mio can also regulate nutrient storage and feeding and that control of food consumption occurs in the IPCs likely via the Mio-driven downregulation of dILP3 mRNA (Docherty et al. 2015).

Insulin in the fly exists as eight (1-8) distinct homologs denoted as Drosophila insulin-like-peptides (dILPs). In larvae, five of the eight dILPs (dILPs 1-5) are secreted from specialized neurosecretory cells known as IPCs found in the brain. IPC ablation decreases adult and larval size and increases circulating glucose and trehalose levels, which can be rescued by restoring dILP2 expression (Rulifson et al. 2002). In addition to the brain, several dILPs are expressed in multiple tissues, including the fat body, depending on fly developmental stage (Brogiolo et al. 2001).

Similar to mammalian insulin, dILP secretion is controlled by nutrient availability. Under starvation and poor amino acid conditions, transcript levels of many IPC-originating $d I L P s$ are altered with some dILP proteins being sequestered to IPCs as well (Ikeya et al. 2002, Géminard et al. 2009). Contrary to IPC produced dILPs, dILP6, which originates in the fat body, is increased in response to starvation (Slaidina et al. 2009). The known physiological functions of dILPs are varied and, depending on the developmental stage of the organisms, include the regulation of organismal growth, cell size, lifespan, lipid storage, and carbohydrate metabolism (Brogiolo et al. 2001, Broughton et al. 2008, Slaidina et al. 2009, Grönke et al. 2010).

Activation and regulation of the insulin signaling pathway is highly conserved in the fly and is a key component of lipid and carbohydrate mobilization, uptake, and storage. Recent studies have demonstrated that the release of dILPs from the IPCs is controlled by changes in amino acid and trehalose levels in a TORdependent manner as well as lipids involving the leptin homolog unpaired 2 (Géminard et al. 2009, Rajan \& Perrimon 2012, Kim \& Neufeld 2015). dILP secretion is also regulated by the Drosophila short neuropeptide $\mathrm{F}$ (sNPF), an ortholog of mammalian neuropeptide Y (Lee et al. 2008). Overexpression of either sNPF or its receptor, sNPFR1, results in increased food intake and overall organismal size and, at the molecular level, downregulation of fat body AKT signaling (Lee et al. 2004, 2008). sNPF orchestrates these effects by controlling dILP secretion via ERK signaling in IPCs (Lee et al. 2008). Secreted dILPs circulate and bind to Drosophila InR causing the receptor to oligomerize and activate a highly conserved set of molecular events that lead to AKT activation (Garofalo 2002, Oldham \& Hafen 2003). Active Drosophila AKT inhibits many of the same metabolic targets as mammalian AKT including dFOXO, dTSC2, and GSK3 $\beta$ (Garofalo 2002).

Additional lipid regulatory components conserved in the fly include the Drosophila sterol regulatory elementbinding protein (dSREBP) transcription factor. Unlike in mammals where sterols regulate SREBP activation, in the cholesterol auxotrophic fly, dSREBP is controlled by intracellular levels of phosphatidylethanolamine (PE), the most abundant phospholipid in flies, and undergoes proteolytic cleavage in theabsenceof phospholipids leading to transcription of genes for fatty acid and phospholipid biosynthesis (Dobrosotskaya et al. 2002, Seegmiller et al. 2002). Inducing dSREBP activity by decreasing PE not only impacts whole-body lipid homeostasis, but also leads to cardiac hyperlipidemia and dysfunction (Lim et al. 2011). 
Using a Drosophila model of obesity-associated heart dysfunction, Diop and coworkers demonstrated that dSREBP contributed to cardiac lipotoxicity in flies fed a high-fat diet, highlighting a potential role for SREBP in the control of human obesity-associated cardiomyopathies (Diop et al. 2015). Drosophila also controls lipid levels by modulation of lipid storage via the fly perilipin homolog Lsd2 that resides on the surface of lipid droplets (Grönke et al. 2003, Teixeira et al. 2003).

Lipid homeostasis is also regulated by $\mathrm{AKH}-$ dependent lipid mobilization, although the precise mechanisms by which AKH promotes lipid release from the fat body is not fully understood (Trinh \& Boulianne 2013). Binding of AKH to its receptor activates glycogen phosphorylase leading to breakdown of glycogen stores and subsequent synthesis of trehalose (Leopold \& Perrimon 2007). Control of lipid stores by AKH is less clear and is thought to involve a mechanism similar to fat mobilization in mammalian adipose tissue. AKH binding to the $\mathrm{AKH}$ receptor stimulates Brummer lipase activity, a homolog of human adipose triglyceride lipase, leading to breakdown of TAG lipid droplet stores and release of DAG into hemolymph (Trinh \& Boulianne 2013). Secretion of AKH relies on the activity of AMPK, whose function as an energy sensor is conserved in Drosophila (Pan \& Hardie 2002, Braco et al. 2012). In the fly, depleting AMPK activity produces small larvae with depleted TAG stores that die in the pupal stage (Bland et al. 2010). This phenotype was shown to be due to a requirement for AMPK in the visceral musculature to promote normal gut function and subsequent uptake of dietary nutrients (Bland et al. 2010). Several other important studies on AMPK in the fly have described a conserved role for the energy sensor in autophagy and organismal longevity, starvation, and maintenance of cell structure, further highlighting Drosophila as a model tool in understanding the physiological impact and molecular mechanisms of nutrient sensing and energy expenditure (Lee et al. 2007, Johnson et al. 2010, Stenesen et al. 2013, Ulgherait et al. 2014). However, with regards to lifespan, treatment of flies with the AMPK agonist metformin failed to increase fly longevity - resulting in a dose-response increase in animal mortality; yet, metformin did activate AMPK and decrease TAG stores (Jafari et al. 2007, Slack et al. 2012). Interestingly, metformin also activates the TOR pathway, independently of AMPK, suggesting that off-target effects of the drug may be a contributing factor and that the function of metformin with regards to lifespan may prove more complex (Kalender et al. 2010).

\section{Metabolic programming in the offspring}

\section{Larval influence on the adult}

In addition to the influences of parental diet, the contributions of gestational and early childhood nutrition on the progeny are key for understanding the mechanisms of metabolic programming. Many studies have used Drosophila to successfully model the effects of caloric restriction during early development (i.e. at the larval stage) on adult lifespan and reproductive capacity (Min et al. 2006, Aguila et al. 2007, 2013, Kolss et al. 2009, Andersen et al. 2010, May et al. 2015). Several reports have also demonstrated the metabolic influences of larval overnutrition on adulthood. Feeding larvae a high-sucrose diet significantly prolonged pupation time and produced adults with heightened levels of whole-body lipids and protein (Musselman et al. 2011, Rovenko et al. 2015a). High-sucrose-fed larvae exhibited increased circulating dILPs in hemolymph; whether this continues into adulthood has not been reported; however, these adults did show increased amounts of brain dILP mRNAs (Musselman et al. 2011, Rovenko et al. 2015a). Interestingly, adults raised on high-sucrose diet as larvae also exhibited decreased lipid peroxides and reduced superoxide dismutase mRNA and activity levels, but increased catalase mRNA and activity compared with controls on a low-sucrose high-protein diet (Rovenko et al. 2015a). When comparing the impact of rearing larvae on glucose versus fructose, while both sugars produced an obese-like phenotype, fructose-fed larvae consumed more food, and adults had increased stores of carbohydrates and lipids and decreased dILP mRNAs compared with glucose-fed controls (Rovenko et al. 2015b). However, glucose-fed larvae had prolonged pupation rates and increased mortality (Rovenko et al. 2015b). Conversely, access to excess dietary protein early in life proved beneficial for survival of physical stress including exposure to extreme temperatures and generated females with increased fecundity (Andersen et al. 2010).

\section{Parental influence}

In light of the global obesity epidemic and the increased prevalence of maternal obesity, a greater understanding of how parental diet influences offspring health as well as its impact on subsequent generations is of paramount importance. The benefits afforded by the fly, including ease of genetic and dietary manipulation, a rapid life cycle, conserved metabolic tissues, and signaling pathways, make it an ideal tool for elucidating molecular mechanisms of parental metabolic programming. Several Drosophila studies have focused on the contribution of parental diet on offspring health focusing on both underand overnutrition (Vijendravarma et al. 2010, Valtonen et al. 2012, Matzkin et al. 2013, Colines et al. 2015, Hardy et al. 2015).

When male and female Drosophila were exposed to isocaloric diets that varied in protein and sucrose concentrations, flies fed a high-sucrose, low-protein diet had elevated levels of whole-body glycogen, decreased protein amounts, and females laid fewer 
eggs than flies raised on a low-sucrose, high-protein diet (Matzkin et al. 2013) (Table 1). Although progeny from both groups were reared on standard diets, offspring of the high-sucrose, low-protein parents underwent a longer metamorphosis than offspring from high-protein, low-sucrose parents (Matzkin et al. 2013). However, while developmental timing was effected, altering the parental diet did not impact offspring survival, but it did alter offspring reproduction (Matzkin et al. 2013). Female offspring of highsucrose, low-protein parents produced fewer eggs and exhibited increased body weight and overall glycogen content compared with females from low-sucrose, high-protein parents (Matzkin et al. 2013). Decreasing both dietary sucrose and protein to one quarter of the amounts of a general laboratory fly diet resulted in a less profound result than the high-sucrose diet when both parents were reared on the malnourished diet, females produced heavier eggs than those fed a standard diet (Vijendravarma et al. 2010). When eggs of malnourished parents were laid on nutrient-poor food, they pupated at a faster rate than eggs from standard diet-fed parents (Vijendravarma et al. 2010). Studies in the fly have also demonstrated that a carbohydrateenriched parental diet can ameliorate the influence of mature parental age on offspring asymmetry relative to old parents reared solely on a protein-rich diet (Colines et al. 2015).

These data demonstrate that altering parental diet in Drosophila, as in mammals, not only produces reproductive repercussions in the parents, but also impacts offspring health. However, whether the observed impact of diet on parental and offspring health is a result of excess sugar, decreased protein, or both remains to be understood. One study has specifically focused on the contribution of a low-protein parental diet on developmental programming and demonstrated that offspring from low-protein-fed parents had longer developmental times relative to progeny from standard diet-fed parents and when only a single parent was malnourished (Valtonen et al. 2012). It is interesting to note that the offspring developmental time when only a single parent was malnourished was shorter than the standard diet timing, but timing of progeny from two malnourished parents was not faster than the single-parent result, but rather slower than both single malnourished parent progeny and the control standard parent progeny. With regards to severe malnourishment, studies have shown that selecting for starvation-resistant flies produces cohorts with altered metabolic features (SchwasingerSchmidt et al. 2012, Hardy et al. 2015). One particular group demonstrated that selecting for starvation-resistant flies for over 65 generations produced organisms with anatomically mislocalized hearts that had decreased contractility and were dilated (Hardy et al. 2015). These cardiac dysfunctions correlated with an accumulation of lipids in the dorsal cuticle, since prolonged fasting of these animals was able to rescue the observed dilation and impaired contractility (Hardy et al. 2015). Interestingly, in another study, selecting for flies exposed to a high-protein diet over 17 generations produced progeny with increased total body mass and lipids and significantly increased mortality rates relative to standard fed controls (Kristensen et al. 2011). Taken together, these studies demonstrate that the dietary inclination of each parent has a complex impact on the offspring and that

Table 1 Effect of high sucrose diet on metabolic programming in Drosophila.

\begin{tabular}{|c|c|c|c|}
\hline & $\begin{array}{l}\text { Paternal high sucrose } \\
\text { Ost et al. (2014) }\end{array}$ & $\begin{array}{l}\text { Maternal high sucrose } \\
\text { Buescher et al. (2013) }\end{array}$ & $\begin{array}{l}\text { Parental high sucrose - low protein } \\
\text { Matzkin et al. (2013) }\end{array}$ \\
\hline F0 & $\uparrow$ TAG adult stage & $\begin{array}{l}\uparrow \text { TAG, trehalose, and Adult stage } \\
\text { glycogen } \\
\downarrow \text { Glucose and body } \\
\text { weight }\end{array}$ & $\begin{array}{l}\uparrow \text { Glycogen; } \downarrow \text { Protein } \quad \text { Adult stage } \\
\text { Fewer eggs laid }\end{array}$ \\
\hline \multirow[t]{2}{*}{$\mathrm{F} 1$} & $\begin{array}{l}\uparrow \text { Body weight (adult males and } \\
\text { females) } \\
\text { Obesogenic Challenge (adult } \\
\text { males and females): } \\
\uparrow \text { Body weight, TAG, and lipid } \\
\text { droplet size } \\
\leftrightarrow \text { Development time and body } \\
\text { size }\end{array}$ & $\begin{array}{l}\text { Larval stage (males): } \\
\quad \uparrow \text { Glucose and trehalose } \\
\downarrow \text { Glycogen and cholesterol; } \\
\leftrightarrow \text { TAG } \\
\text { Altered lipid and cholesterol gene expression }\end{array}$ & $\begin{array}{l}\uparrow \text { Development time (males and females) } \\
\text { Fewer eggs laid (adult females) }\end{array}$ \\
\hline & $\begin{array}{l}\text { Desilenced peri-centric X } \\
\text { chromosome (adult females) }\end{array}$ & $\begin{array}{l}\text { Adult stage (males): } \\
\downarrow \text { Glucose and body weight* } \\
\uparrow \text { Trehalose*, TAG*, and glycogen } \\
\text { Altered lipid and cholesterol gene expression }\end{array}$ & \\
\hline F2 & $\begin{array}{l}\text { No effect observed (adult males; } \\
\text { females unreported) }\end{array}$ & $\begin{array}{l}\text { Larval males: } \\
\quad \uparrow \text { Glucose and trehalose } \\
\text { Larval females: } \\
\quad \uparrow \text { Trehalose; } \downarrow \text { TAG }\end{array}$ & Not reported \\
\hline
\end{tabular}

*Observed impact is exacerbated by obesogenic challenge. 
the combined influence of both parent's diets leads to a further complexity in offspring health.

\section{Paternal influence}

Teasing out the contribution to metabolic programming of each parent is imperative in order to elucidate the molecular mechanisms at play in controlling offspring health. Work in Drosophila has demonstrated a paternal contribution to metabolic programming (Valtonen et al. 2012, Ost et al. 2014, Aldrich \& Maggert 2015). Exposure of male flies to a low-protein diet from embryo through adulthood resulted in progeny with shortened developmental times and larger male offspring, but no change in female offspring size, relative to paternal males raised on standard food (Valtonen et al. 2012). When dietary sucrose rather than protein amounts were altered in paternal flies, it caused paternal TAG levels to increase in correlation with sugar concentrations and also resulted in a concentration-dependent increase in offspring body weight (Ost et al. 2014). Offspring of high-sucrose-fed males appeared to be presensitized to an obesogenic diet since, upon exposure to the diet, body weight, TAG, and lipid droplet size all increased (Ost et al. 2014). Interestingly, this obese phenotype was evident in progeny whose fathers had only been on a high sucrose diet for 2 days (Ost et al. 2014). Developmental times and overall offspring size remained unchanged regardless of the paternal diet (Ost et al. 2014). Moreover, there was no apparent transgenerational impact of the high-sucrose paternal diet to generations after F1 (Ost et al. 2014).

Taking full advantage of the benefits of fly genetics and dietary manipulation, two groups have uncovered profound insight into the mechanistic underpinnings of metabolic programming, highlighting a key role for genomic alteration (Ost et al. 2014, Aldrich \& Maggert 2015). Male flies fed a protein-rich diet exhibit decreased rDNA copy numbers resulting in rDNA instability in both somatic and germ cells, which was InR-dependent (Aldrich \& Maggert 2015). To investigate the impact on germline transmission, Aldrich and coworkers crossed these male flies with females carrying an rDNAdeficient compound $X$ chromosome to generate female progeny whose only source of rDNA originated from the Y-linked $r D N A$ gene. This genetic strategy revealed that the rDNA phenotype was transferred to female offspring, resulting in progeny with reduced rDNA copy numbers and persisted for up to two generations even though progeny were fed a standard diet (Aldrich \& Maggert 2015). The observation that the generational impact on rRNA copy number was blocked by the inhibition of the TOR pathway coupled with the fact that the impact of protein-rich diet on fathers is InR-dependent implicate the insulin/TOR signaling pathway as a mechanism of germline rDNA instability (Aldrich \& Maggert 2015). How paternal-diet-induced rDNA instability impacts offspring gene expression and subsequent health is not known; however, alterations to rDNA integrity have been linked to changes in the global chromatin state and organismal longevity (Paredes \& Maggert 2009, Kobayashi 2011, Kwan et al. 2013).

Changes in fly paternal diet have also been associated with an altered offspring chromatin state (Ost et al. 2014). Male Drosophila fed a high-sucrose diet produced offspring with desilenced pericentric heterochromatin on the $X$ chromosome and an increase in gene expression including genes involved in energy metabolism as well as several unknown genes (Ost et al. 2014). Gene desilencing was also observed in the sperm of the high-sucrose-fed fathers, suggesting that dietinduced changes to sperm gene expression is a vehicle by which progeny gene expression is influenced (Ost et al. 2014).

\section{Maternal influence}

Several studies in Drosophila have focused on understanding the contribution of maternal diet to metabolic programming (Prasad et al. 2003, Vijendravarma et al. 2010, Valtonen et al. 2012, Buescher et al. 2013, Matzkin et al. 2013). Most maternal programming studies have focused on the influence of undernourishment on progeny health and have demonstrated that females exposed to a protein- and sucrose-poor diet produce heavier eggs (Vijendravarma et al. 2010). However, decreased nutrition in the form of sucrose and protein also results in decreased egg production and fewer mating events for females (Chapman \& Partridge 1996). When maternal dietary protein levels were decreased, females produced larger progeny with shorter developmental times compared with offspring of protein-rich females (Valtonen et al. 2012). Additionally, protein-poor females produced progeny with increased survivorship at the larval stage compared with offspring of protein-rich females; however, by the pupal stage, survivorship between both groups was comparable (Prasad et al. 2003). It is interesting to note that, although protein-deficient females generated larger offspring, actual maternal egg production and ovary size correlate negatively with dietary protein concentrations (Drummond-Barbosa \& Spradling 2001). While the molecular mechanisms by which maternal diet controls reproduction and offspring health are not completely understood, there is evidence demonstrating a role for Hedgehog and insulin signaling pathways in regulating the diet-induced proliferation of ovarian stem cells (Drummond-Barbosa \& Spradling 2001, Hsu et al. 2008, Hsu \& Drummond-Barbosa 2009, Hartman et al. 2013).

Most maternal diet studies in Drosophila focus on undernourished conditions; however, to understand the molecular mechanisms of maternal overnutrition (i.e. maternal obesity), we developed a fly model that incorporated comparing the effects of a high- versus 
low-sucrose diet on offspring health (Buescher et al. 2013). Rearing female flies on a high-sucrose diet produced an obese-like phenotype, marked by increased whole-body TAG, glycogen, and trehalose, insulin resistance, and elevated dILP expression compared with females on a low-sucrose diet (Buescher et al. 2013; J G Duncan and R T Brookheart, unpublished observations). High-sucrosefed females produced male offspring with increased whole-body glucose and trehalose levels, while female progeny only had decreased levels of whole-body cholesterol (Buescher et al. 2013). Changes in gene expression levels of male offspring were assessed by RNA sequencing, which revealed several differentially expressed genes involved in lipid and carbohydrate metabolism, including lipases Lip3 and CG17191, fatty acid synthase, acetyl-CoA-carboxylase, pyruvate kinase, enolase, and a putative sugar transporter CG4797 (Buescher et al. 2013). Offspring of high-sucrose-fed females were presensitized to an obesogenic diet, exhibiting increased whole-body TAG, glycogen, and trehalose levels as well as altered expression of several carbohydrate and lipid metabolic genes (Buescher et al. 2013). A transgenerational effect was also observed, whereby F2 male progeny of highsucrose-fed F0 females showed increased glycogen and trehalose levels, while F2 females displayed increased trehalose and decreased TAG levels (Buescher et al. 2013). The factors contributing to these transgenerational observations are currently being investigated in the lab and are hypothesized to involve inheritance of altered maternal mitochondria - a phenomena that has been reported in mammalian metabolic programming studies; however, these reports only investigated the F1 generation (Grindler \& Moley 2013). The multigenerational reach of the maternal obesogenic diet as well as the transmission of maternal mitochondria makes the organelle a strong candidate for influencing metabolic programming across generations.

\section{Conclusion}

The fly is quickly emerging as an important ally for understanding human metabolic diseases, a trend in part owed to the highly conserved series of metabolic tissues and pathways present within the fly and a multitude of genetic tools available (Liu \& Huang 2013, Rajan \& Perrimon 2013). As the prevalence of maternal and paternal obesity increases, the threat to offspring health and to subsequent generations will only worsen, making Drosophila an invaluable tool in uncovering the complexity of metabolic programming.

\section{Declaration of interest}

The authors declare that there is no conflict of interest that could be perceived as prejudicing the impartiality of the review.

\section{Funding}

This work was supported by grants from the American Heart Association (IRG5450013 and GRNT12080056 to J G Duncan), the Washington University Diabetes Research Center (P30DK020579 to J G Duncan), and the National Institutes of Health (K12HD001459 to R T Brookheart).

\section{References}

Agrawal N, Pallos J, Slepko N, Apostol BL, Bodai L, Chang L-WW, Chiang A-SS, Thompson LM \& Marsh JL 2005 Identification of combinatorial drug regimens for treatment of Huntington's disease using Drosophila. PNAS 102 3777-3781. (doi:10.1073/pnas.0500055102)

Aguila JR, Suszko J, Gibbs AG \& Hoshizaki DK 2007 The role of larval fat cells in adult Drosophila melanogaster. Journal of Experimental Biology 210 956-963. (doi:10.1242/jeb.001586)

Aguila JR, Hoshizaki DK \& Gibbs AG 2013 Contribution of larval nutrition to adult reproduction in Drosophila melanogaster. Journal of Experimental Biology 216 399-406. (doi:10.1242/jeb.078311)

Aldrich JC \& Maggert KA 2015 Transgenerational inheritance of dietinduced genome rearrangements in Drosophila. PLoS Genetics 11 e1005148. (doi:10.1371/journal.pgen.1005148)

Andersen LH, Kristensen TN, Loeschcke V, Toft S \& Mayntz D 2010 Protein and carbohydrate composition of larval food affects tolerance to thermal stress and desiccation in adult Drosophila melanogaster. Journal of Insect Physiology 56 336-340. (doi:10.1016/j.jinsphys.2009.11.006)

Apidianakis Y \& Rahme LG 2011 Drosophila melanogaster as a model for human intestinal infection and pathology. Disease Models \& Mechanisms 4 21-30. (doi:10.1242/dmm.003970)

Arrese EL \& Soulages JL 2010 Insect fat body: energy, metabolism, and regulation. Annual Review of Entomology 55 207-225. (doi:10.1146/ annurev-ento-112408-085356)

Arrese EL, Canavoso LE, Jouni ZE, Pennington JE, Tsuchida K \& Wells MA 2001 Lipid storage and mobilization in insects: current status and future directions. Insect Biochemistry and Molecular Biology 31 7-17. (doi:10.1016/S0965-1748(00)00102-8)

Baker KD \& Thummel CS 2007 Diabetic larvae and obese flies-emerging studies of metabolism in Drosophila. Cell Metabolism 6 257-266. (doi:10.1016/j.cmet.2007.09.002)

Barker DJ 1990 The fetal and infant origins of adult disease. BMJ 3011111. (doi:10.1136/bmj.301.6761.1111)

Bassett AR, Tibbit C, Ponting CP \& Liu J-L 2013 Highly efficient targeted mutagenesis of Drosophila with the CRISPR/Cas9 system. Cell Reports $\mathbf{4}$ 220-228. (doi:10.1016/j.celrep.2013.06.020)

Baumbach J, Hummel P, Bickmeyer I, Kowalczyk KM, Frank M, Knorr K, Hildebrandt A, Riedel D, Jäckle H \& Kühnlein RP 2014 A drosophila in vivo screen identifies store-operated calcium entry as a key regulator of adiposity. Cell Metabolism 19331-343. (doi:10.1016/j.cmet.2013.12.004)

Beller M, Sztalryd C, Southall N, Bell M, Jäckle H, Auld DS \& Oliver B 2008 COPI complex is a regulator of lipid homeostasis. PLoS Biology $\mathbf{6}$ e292. (doi:10.1371/journal.pbio.0060292)

Biro FM \& Wien M 2010 Childhood obesity and adult morbidities. American Journal of Clinical Nutrition 91 1499S-1505S. (doi:10.3945/ ajcn.2010.28701B)

Birse RT, Choi J, Reardon K, Rodriguez J, Graham S, Diop S, Ocorr K, Bodmer R \& Oldham S 2010 High-fat-diet-induced obesity and heart dysfunction are regulated by the TOR pathway in Drosophila. Cell Metabolism 12 533-544. (doi:10.1016/j.cmet.2010.09.014)

Bland ML, Lee RJ, Magallanes JM, Foskett JK \& Birnbaum MJ 2010 AMPK supports growth in Drosophila by regulating muscle activity and nutrient uptake in the gut. Developmental Biology 344 293-303. (doi:10.1016/j. ydbio.2010.05.010)

Borengasser SJ, Lau F, Kang P, Blackburn ML, Ronis MJJ, Badger TM \& Shankar K 2011 Maternal obesity during gestation impairs fatty acid oxidation and mitochondrial SIRT3 expression in rat offspring at weaning. PLOS ONE 6 e24068. (doi:10.1371/journal.pone.0024068)

Braco JT, Gillespie EL, Alberto GE, Brenman JE \& Johnson EC 2012 Energydependent modulation of glucagon-like signaling in Drosophila via the AMP-activated protein kinase. Genetics 192 457-466. (doi:10.1534/ genetics.112.143610) 
Britton JS, Lockwood WK, Li L, Cohen SM \& Edgar BA 2002 Drosophila's insulin/PI3-kinase pathway coordinates cellular metabolism with nutritional conditions. Developmental Cell 2 239-249. (doi:10.1016/ S1534-5807(02)00117-X)

Brogiolo W, Stocker H, Ikeya T, Rintelen F, Fernandez R \& Hafen E 2001 An evolutionarily conserved function of the drosophila insulin receptor and insulin-like peptides in growth control. Current Biology 11213 221. (doi:10.1016/S0960-9822(01)00068-9)

Broughton S, Alic N, Slack C, Bass T, Ikeya T, Vinti G, Tommasi AM, Driege Y, Hafen E \& Partridge L 2008 Reduction of DILP2 in Drosophila triages a metabolic phenotype from lifespan revealing redundancy and compensation among DILPs. PLOS ONE 3 e3721. (doi:10.1371/journal. pone.0003721)

Bruce KD, Cagampang FR, Argenton M, Zhang J, Ethirajan PL, Burdge GC, Bateman AC, Clough GF, Poston L, Hanson MA et al. 2009 Maternal high-fat feeding primes steatohepatitis in adult mice offspring, involving mitochondrial dysfunction and altered lipogenesis gene expression. Hepatology 50 1796-1808. (doi:10.1002/hep.23205)

Buescher JL, Musselman LP, Wilson CA, Lang T, Keleher M, Baranski TJ \& Duncan JG 2013 Evidence for transgenerational metabolic programming in Drosophila. Disease Models \& Mechanisms 6 1123-1132. (doi:10.1242/dmm.011924)

Campbell JE \& Drucker DJ 2015 Islet $\alpha$ cells and glucagon - critical regulators of energy homeostasis. Nature Reviews Endocrinology 11 329-338. (doi:10.1038/nrendo.2015.51)

Carone BR, Fauquier L, Habib N, Shea JM, Hart CE, Li R, Bock C, Li C, Gu H, Zamore PD et al. 2010 Paternally induced transgenerational environmental reprogramming of metabolic gene expression in mammals. Cell 143 1084-1096. (doi:10.1016/j.cell.2010.12.008)

Casas-Agustench P, Fernandes FS, Tavares do Carmo MG, Visioli F, Herrera E \& Dávalos A 2015 Consumption of distinct dietary lipids during early pregnancy differentially modulates the expression of microRNAs in mothers and offspring. PLOS ONE $\mathbf{1 0}$ e0117858. (doi:10.1371/journal.pone.0117858)

Catalano PM, Farrell K, Thomas A, Huston-Presley L, Mencin P, de Mouzon SH \& Amini SB 2009 Perinatal risk factors for childhood obesity and metabolic dysregulation. American Journal of Clinical Nutrition $\mathbf{9 0}$ 1303-1313. (doi:10.3945/ajen.2008.27416)

Ceelen M, van Weissenbruch MM, Roos JC, Vermeiden JPW, van Leeuwen FE \& Delemarre-van de Waal HA 2007 Body composition in children and adolescents born after in vitro fertilization or spontaneous conception. Journal of Clinical Endocrinology \& Metabolism 92 3417-3423.

Ceelen M, van Weissenbruch MM, Vermeiden JPW, van Leeuwen FE \& Delemarre-van de Waal HA 2008 Cardiometabolic differences in children born after in vitro fertilization: follow-up study. Journal of Clinical Endocrinology \& Metabolism 93 1682-1688. (doi:10.1210/ jc.2007-2432)

Chapman T \& Partridge L 1996 Female fitness in Drosophila melanogaster: an interaction between the effect of nutrition and of encounter rate with males. Proceedings of the Royal Socieity Biological Sciences 263 755759. (doi:10.1098/rspb.1996.0113)

Clausen TD, Mathiesen ER, Hansen T, Pedersen O, Jensen DM, Lauenborg J, Schmidt L \& Damm P 2009 Overweight and the metabolic syndrome in adult offspring of women with diet-treated gestational diabetes mellitus or type 1 diabetes. Journal of Clinical Endocrinology \& Metabolism 94 2464-2470. (doi:10.1210/jc.2009-0305)

Colines B, Rodríguez NC, Hasson ER, Carreira V \& Frankel N 2015 Parental age influences developmental stability of the progeny in Drosophila. Proceedings. Biological Sciences/The Royal Society 28220142437. (doi:10.1098/rspb.2014.2437)

Colombani J, Raisin S, Pantalacci S, Radimerski T, Montagne J \& Léopold P 2003 A nutrient sensor mechanism controls Drosophila growth. Cell 114 739-749. (doi:10.1016/S0092-8674(03)00713-X)

Colombani J, Bianchini L, Layalle S, Pondeville E, Dauphin-Villemant C, Antoniewski C, Carré C, Noselli S \& Léopold P 2005 Antagonistic actions of ecdysone and insulins determine final size in Drosophila. Science 310 667-670. (doi:10.1126/science.1119432)

del Valle Rodríguez A, Didiano D \& Desplan C 2012 Power tools for gene expression and clonal analysis in Drosophila. Nature Methods 9 47-55. (doi:10.1038/nmeth.1800)

Delanoue R, Slaidina M \& Léopold P 2010 The steroid hormone ecdysone controls systemic growth by repressing dMyc function in
Drosophila fat cells. Developmental Cell 18 1012-1021. (doi:10.1016/j. devcel.2010.05.007)

Deshpande SA, Carvalho GB, Amador A, Phillips AM, Hoxha S, Lizotte KJ \& Ja WW 2014 Quantifying Drosophila food intake: comparative analysis of current methodology. Nature Methods 11 535-540. (doi:10.1038/ nmeth.2899)

Diesel JC, Eckhardt CL, Day NL, Brooks MM, Arslanian SA \& Bodnar LM 2015 Is gestational weight gain associated with offspring obesity at 36 months? Pediatric Obesity 10 305-310. (doi:10.1111/ijpo.2015.10.issue-4)

Dietzl G, Chen D, Schnorrer F, Su K-C, Barinova Y, Fellner M, Gasser B, Kinsey K, Oppel S, Scheiblauer S et al. 2007 A genome-wide transgenic RNAi library for conditional gene inactivation in Drosophila. Nature $\mathbf{4 4 8}$ 151-156. (doi:10.1038/nature05954)

Diop SBB, Bisharat-Kernizan J, Birse RTT, Oldham S, Ocorr K \& Bodmer R 2015 PGC-1/spargel counteracts high-fat-diet-induced obesity and cardiac lipotoxicity downstream of TOR and brummer ATGL lipase. Cell Reports 10 1572-1584. (doi:10.1016/j.celrep.2015.02.022)

Dobrosotskaya IY, Seegmiller AC, Brown MS, Goldstein JL \& Rawson RB 2002 Regulation of SREBP processing and membrane lipid production by phospholipids in Drosophila. Science 296 879-883. (doi:10.1126/ science.1071124)

Docherty JEB, Manno JE, McDermott JE \& DiAngelo JR 2015 Mio acts in the Drosophila brain to control nutrient storage and feeding. Gene $\mathbf{5 6 8}$ 190-195. (doi:10.1016/j.gene.2015.05.055)

Dokras A, Baredziak L, Blaine J, Syrop C, VanVoorhis BJ \& Sparks A 2006 Obstetric outcomes after in vitro fertilization in obese and morbidly obese women. Obstetrics and Gynecology 108 61-69. (doi:10.1097/01. AOG.0000219768.08249.b6)

Drummond-Barbosa D \& Spradling AC 2001 Stem cells and their progeny respond to nutritional changes during Drosophila oogenesis. Developmental Biology 231 265-278. (doi:10.1006/dbio.2000.0135)

Fernández-Moreno MA, Farr CL, Kaguni LS \& Garesse R 2007 Drosophila melanogaster as a model system to study mitochondrial biology. Methods in Molecular Biology 372 33-49. (doi:10.1007/978-1-59745-365-3)

Forno E, Young OM, Kumar R, Simhan H \& Celedon JC 2014 Maternal obesity in pregnancy, gestational weight gain, and risk of childhood asthma. Pediatrics 134 e535-e546. (doi:10.1542/peds.2014-0439)

Freedman DS, Khan LK, Serdula MK, Dietz WH, Srinivasan SR \& Berenson GS 2005 The relation of childhood BMI to adult adiposity: the Bogalusa Heart Study. Pediatrics 115 22-27.

Freedman DS, Dietz WH, Srinivasan SR \& Berenson GS 2009 Risk factors and adult body mass index among overweight children: the Bogalusa Heart Study. Pediatrics 123 750-757. (doi:10.1542/peds.2008-1284)

Gallardo JM, Gómez-López J, Medina-Bravo P, Juárez-Sánchez F, Contreras-Ramos A, Galicia-Esquivel M, Sánchez-Urbina R \& KlünderKlünder M 2015 Maternal obesity increases oxidative stress in the newborn. Obesity 23 1650-1654. (doi:10.1002/oby.21159)

Garofalo RS 2002 Genetic analysis of insulin signaling in Drosophila. Trends in Endocrinology and Metabolism: TEM 13 156-162. (doi:10.1016/S1043-2760(01)00548-3)

Géminard C, Rulifson EJ \& Léopold P 2009 Remote control of insulin secretion by fat cells in Drosophila. Cell Metabolism 10 199-207. (doi:10.1016/j.cmet.2009.08.002)

Gemma C, Sookoian S, Alvariñas J, García SI, Quintana L, Kanevsky D, González CD \& Pirola CJ 2006 Mitochondrial DNA depletion in small- and large-for-gestational-age newborns. Obesity 14 2193-2199. (doi:10.1038/oby.2006.257)

Gemma C, Sookoian S, Alvariñas J, García SI, Quintana L, Kanevsky D, González CD \& Pirola CJ 2009 Maternal pregestational BMI is associated with methylation of the PPARGC1A promoter in newborns. Obesity 17 1032-1039. (doi:10.1038/oby.2008.605)

Giritharan G, Talbi S, Donjacour A, Di Sebastiano F, Dobson AT \& Rinaudo PF 2007 Effect of in vitro fertilization on gene expression and development of mouse preimplantation embryos. Reproduction 134 63-72. (doi:10.1530/REP-06-0247)

Grindler NM \& Moley KH 2013 Maternal obesity, infertility and mitochondrial dysfunction: potential mechanisms emerging from mouse model systems. Molecular Human Reproduction 19 487-494. (doi:10.1093/molehr/gat026)

Grönke S, Beller M, Fellert S, Ramakrishnan H, Jäckle H \& Kühnlein RP 2003 Control of fat storage by a Drosophila PAT domain protein. Current Biology : CB 13 603-606. (doi:10.1016/S0960-9822(03)00175-1) 
Grönke S, Mildner A, Fellert S, Tennagels N, Petry S, Müller G, Jäckle H \& Kühnlein RP 2005 Brummer lipase is an evolutionary conserved fat storage regulator in Drosophila. Cell Metabolism 1 323-330. (doi:10.1016/j.cmet.2005.04.003)

Grönke S, Clarke D-F, Broughton S, Andrews TD \& Partridge L 2010 Molecular evolution and functional characterization of Drosophila insulin-like peptides. PLOS Genetics 6 e1000857. (doi:10.1371/journal. pgen.1000857)

Guo Y, Walther TC, Rao M, Stuurman N, Goshima G, Terayama K, Wong JS, Vale RD, Walter P \& Farese R V 2008 Functional genomic screen reveals genes involved in lipid-droplet formation and utilization. Nature 453 657-661. (doi:10.1038/nature06928)

Gutierrez E, Wiggins D, Fielding B \& Gould AP 2007 Specialized hepatocyte-like cells regulate Drosophila lipid metabolism. Nature $\mathbf{4 4 5}$ 275-280. (doi:10.1038/nature05382)

Hales CN \& Barker DJ 1992 Type 2 (non-insulin-dependent) diabetes mellitus: the thrifty phenotype hypothesis. Diabetologia 35 595-601. (doi:10.1007/BF00400248)

Hardy CM, Birse RT, Wolf MJ, Yu L, Bodmer R \& Gibbs AG 2015 Obesityassociated cardiac dysfunction in starvation-selected Drosophila melanogaster. American Journal of Physiology. Regulatory, Integrative and Comparative Physiology 309 R658-R667. (doi:10.1152/ ajpregu.00160.2015)

Hartman TR, Strochlic TI, Ji Y, Zinshteyn D \& O'Reilly AM 2013 Diet controls Drosophila follicle stem cell proliferation via Hedgehog sequestration and release. Journal of Cell Biology 201 741-757. (doi:10.1083/jcb.201212094)

Herbstman JB, Wang S, Perera FP, Lederman SA, Vishnevetsky J, Rundle AG, Hoepner LA, Qu L \& Tang D 2013 Predictors and consequences of global DNA methylation in cord blood and at three years. PLOS ONE 8 e72824. (doi:10.1371/journal.pone.0072824)

Hsu H-J \& Drummond-Barbosa D 2009 Insulin levels control female germline stem cell maintenance via the niche in Drosophila. PNAS 106 1117-1121. (doi:10.1073/pnas.0809144106)

Hsu H-J, LaFever L \& Drummond-Barbosa D 2008 Diet controls normal and tumorous germline stem cells via insulin-dependent and -independent mechanisms in Drosophila. Developmental Biology 313 700-712. (doi:10.1016/j.ydbio.2007.11.006)

Hyun S, Lee JH, Jin H, Nam J, Namkoong B, Lee G, Chung J \& Kim VN 2009 Conserved MicroRNA miR-8/miR-200 and its target USH/FOG2 control growth by regulating PI3K. Cell 139 1096-1108. (doi:10.1016/j. cell.2009.11.020)

Igosheva N, Abramov AY, Poston L, Eckert JJ, Fleming TP, Duchen MR \& McConnell J 2010 Maternal diet-induced obesity alters mitochondrial activity and redox status in mouse oocytes and zygotes. PLOS ONE 5 e10074. (doi:10.1371/journal.pone.0010074)

Ikeya T, Galic M, Belawat P, Nairz K \& Hafen E 2002 Nutrient-dependent expression of insulin-like peptides from neuroendocrine cells in the CNS contributes to growth regulation in Drosophila. Current Biology 12 1293-1300. (doi:10.1016/S0960-9822(02)01043-6)

Jafari M, Khodayari B, Felgner J, Bussel II, Rose MR \& Mueller LD 2007 Pioglitazone: an anti-diabetic compound with anti-aging properties. Biogerontology 8 639-651. (doi:10.1007/s10522-007-9105-7)

Jin H, Kim VN \& Hyun S 2012 Conserved microRNA miR-8 controls body size in response to steroid signaling in Drosophila. Genes \& Development 26 1427-1432. (doi:10.1101/gad.192872.112)

Johnson EC, Kazgan N, Bretz CA, Forsberg LJ, Hector CE, Worthen RJ, Onyenwoke R \& Brenman JE 2010 Altered metabolism and persistent starvation behaviors caused by reduced AMPK function in Drosophila. PLOS ONE 5 e12799. (doi:10.1371/journal.pone.0012799)

Jumbo-Lucioni P, Ayroles JF, Chambers MM, Jordan KW, Leips J, Mackay TF \& De Luca M 2010 Systems genetics analysis of body weight and energy metabolism traits in Drosophila melanogaster. BMC Genomics 11297. (doi:10.1186/1471-2164-11-297)

Kaati G, Bygren LO \& Edvinsson S 2002 Cardiovascular and diabetes mortality determined by nutrition during parents' and grandparents' slow growth period. European Journal of Human Genetics : EJHG 10 682-688. (doi:10.1038/sj.ejhg.5200859)

Kalender A, Selvaraj A, Kim SY, Gulati P, Brûlé S, Viollet B, Kemp BE, Bardeesy N, Dennis P, Schlager JJ et al. 2010 Metformin, independent of AMPK, inhibits mTORC1 in a rag GTPase-dependent manner. Cell Metabolism 11 390-401. (doi:10.1016/j.cmet.2010.03.014)
Kang HL, Benzer S \& Min KT 2002 Life extension in Drosophila by feeding a drug. PNAS 99 838-843. (doi:10.1073/pnas.022631999)

Kim J \& Neufeld TP 2015 Dietary sugar promotes systemic TOR activation in Drosophila through AKH-dependent selective secretion of Dilp3. Nature Communications 6 6846. (doi:10.1038/ncomms7846)

Kim SK \& Rulifson EJ 2004 Conserved mechanisms of glucose sensing and regulation by Drosophila corpora cardiaca cells. Nature 431 316-320. (doi:10.1038/nature02897)

Kobayashi T 2011 How does genome instability affect lifespan? Genes to Cells 16 617-624. (doi:10.1111/j.1365-2443.2011.01519.x)

Kolss M, Vijendravarma RK, Schwaller G \& Kawecki TJ 2009 Life-history consequences of adaptation to larval nutritional stress in Drosophila. Evolution; International Journal of Organic Evolution 63 2389-2401. (doi:10.1111/evo.2009.63.issue-9)

Kristensen TN, Overgaard J, Loeschcke V \& Mayntz D 2011 Dietary protein content affects evolution for body size, body fat and viability in Drosophila melanogaster. Biology Letters 7 269-272. (doi:10.1098/ rsbl.2010.0872)

Kutty RK, Kutty G, Kambadur R, Duncan T, Koonin EV, Rodriguez IR, Odenwald WF \& Wiggert B 1996 Molecular characterization and developmental expression of a retinoid- and fatty acid-binding glycoprotein from Drosophila: a putative lipophorin. Journal of Biological Chemistry 271 20641-20649. (doi:10.1074/jbc.271.34.20641)

Kwan EX, Foss EJ, Tsuchiyama S, Alvino GM, Kruglyak L, Kaeberlein M, Raghuraman MK, Brewer BJ, Kennedy BK \& Bedalov A 2013 A natural polymorphism in rDNA replication origins links origin activation with calorie restriction and lifespan. PLoS Genetics 9 e1003329. (doi:10.1371/journal.pgen.1003329)

Lee K-S, You K-H, Choo J-K, Han Y-M \& Yu K 2004 Drosophila short neuropeptide $\mathrm{F}$ regulates food intake and body size. Journal of Biological Chemistry 279 50781-50789. (doi:10.1074/jbc.M407842200)

Lee JH, Koh H, Kim M, Kim Y, Lee SY, Karess RE, Lee S-H, Shong M, Kim JM, Kim J et al. 2007 Energy-dependent regulation of cell structure by AMP-activated protein kinase. Nature 447 1017-1020. (doi:10.1038/ nature05828)

Lee K-S, Kwon O-Y, Lee JH, Kwon K, Min K-J, Jung S-A, Kim A-K, You K-H, Tatar M \& Yu K 2008 Drosophila short neuropeptide F signalling regulates growth by ERK-mediated insulin signalling. Nature Cell Biology 10 468-475. (doi:10.1038/ncb1710)

Leopold P \& Perrimon N 2007 Drosophila and the genetics of the internal milieu. Nature 450 186-188. (doi:10.1038/nature06286)

Lim HY, Wang W, Wessells RJ, Ocorr K \& Bodmer R 2011 Phospholipid homeostasis regulates lipid metabolism and cardiac function through SREBP signaling in Drosophila. Genes \& Development 25 189-200. (doi:10.1101/gad.1992411)

Liu Z \& Huang X 2013 Lipid metabolism in Drosophila : development and disease using Drosophila system to study lipid metabolism lipids function in Drosophila early development. Acta Biochimica et Biophysica Sinica 45 44-50. (doi:10.1093/abbs/gms105)

Lowe A, Braback L, Ekeus C, Hjern A \& Forsberg B 2011 Maternal obesity during pregnancy as a risk for early-life asthma. Journal of Allergy and Clinical Immunology 128 1102-1107. (doi:10.1016/j.jaci.2011.08.025)

Luzzo KM, Wang Q, Purcell SH, Chi M, Jimenez PT, Grindler N, Schedl T \& Moley KH 2012 High fat diet induced developmental defects in the mouse: oocyte meiotic aneuploidy and fetal growth retardation/brain defects. PLOS ONE 7 e49217. (doi:10.1371/journal.pone.0049217)

Malti N, Merzouk H, Merzouk SA, Loukidi B, Karaouzene N, Malti A \& Narce M 2014 Oxidative stress and maternal obesity: fetoplacental unit interaction. Placenta 35 411-416. (doi:10.1016/j. placenta.2014.03.010)

Matzkin LM, Johnson S, Paight C \& Markow TA 2013 Preadult parental diet affects offspring development and metabolism in Drosophila melanogaster. PLOS ONE 8 e59530. (doi:10.1371/journal.pone.0059530)

May CM, Doroszuk A \& Zwaan BJ 2015 The effect of developmental nutrition on life span and fecundity depends on the adult reproductive environment in Drosophila melanogaster. Ecology and Evolution 5 1156-1168. (doi:10.1002/ece3.2015.5.issue-6)

Melo AM, Benatti RO, Ignacio-Souza LM, Okino C, Torsoni AS, Milanski M, Velloso LA \& Torsoni MA 2014 Hypothalamic endoplasmic reticulum stress and insulin resistance in offspring of mice dams fed high-fat diet during pregnancy and lactation. Metabolism 63 682-692. (doi:10.1016/j.metabol.2014.02.002) 
Metwally M, Ong KJ, Ledger WL \& Li TC 2008 Does high body mass index increase the risk of miscarriage after spontaneous and assisted conception? A meta-analysis of the evidence. Fertility and Sterility $\mathbf{9 0}$ 714-726. (doi:10.1016/j.fertnstert.2007.07.1290)

Min K-J, Hogan MF, Tatar M \& O'Brien DM 2006 Resource allocation to reproduction and soma in Drosophila: a stable isotope analysis of carbon from dietary sugar. Journal of Insect Physiology 52 763-770. (doi:10.1016/j.jinsphys.2006.04.004)

Musselman LP, Fink JL, Narzinski K, Ramachandran PV, Hathiramani SS, Cagan RL \& Baranski TJ 2011 A high-sugar diet produces obesity and insulin resistance in wild-type Drosophila. Disease Models \& Mechanisms 4 842-849. (doi:10.1242/dmm.007948)

Musselman LP, Fink JL, Ramachandran PV, Patterson BW, Okunade AL, Maier E, Brent MR, Turk J \& Baranski TJ 2013 Role of fat body lipogenesis in protection against the effects of caloric overload in drosophila. Journal of Biological Chemistry 288 8028-8042. (doi:10.1074/jbc. M112.371047)

Na J, Musselman LP, Pendse J, Baranski TJ, Bodmer R, Ocorr K \& Cagan R 2013 A Drosophila model of high sugar diet-induced cardiomyopathy. PLoS Genetics 9 e1003175. (doi:10.1371/journal.pgen.1003175)

Ng S-F, Lin RCY, Laybutt DR, Barres R, Owens JA \& Morris MJ 2010 Chronic high-fat diet in fathers programs $\beta$-cell dysfunction in female rat offspring. Nature 467 963-966. (doi:10.1038/nature09491)

Nohr EA, Timpson NJ, Andersen CS, Davey Smith G, Olsen J \& Sorensen TI 2009 Severe obesity in young women and reproductive health: the Danish National Birth Cohort. PLoS ONE 4 e8444. (doi:10.1371/journal. pone.0008444)

Noyes BE, Katz FN \& Schaffer MH 1995 Identification and expression of the Drosophila adipokinetic hormone gene. Molecular and Cellular Endocrinology 109 133-141. (doi:10.1016/0303-7207(95)03492-P)

O'Brien TE, Ray JG \& Chan W-S 2003 Maternal body mass index and the risk of preeclampsia: a systematic overview. Epidemiology 14 368-374. (doi:10.1097/01.EDE.0000059921.71494.D1)

Okamoto N, Yamanaka N, Yagi Y, Nishida Y, Kataoka H, O'Connor MB \& Mizoguchi A 2009 A fat body-derived IGF-like peptide regulates postfeeding growth in Drosophila. Developmental Cell 17 885-891. (doi:10.1016/j.devcel.2009.10.008)

Oldham S \& Hafen E 2003 Insulin/IGF and target of rapamycin signaling: a TOR de force in growth control. Trends in Cell Biology 13 79-85. (doi:10.1016/S0962-8924(02)00042-9)

Oldham S, Montagne J, Radimerski T, Thomas G \& Hafen E 2000 Genetic and biochemical characterization of dTOR, the Drosophila homolog of the target of rapamycin. Genes \& Development 14 2689-2694.

Ost A, Lempradl A, Casas E, Weigert M, Tiko T, Deniz M, Pantano L, Boenisch U, Itskov PM, Stoeckius M et al. 2014 Paternal diet defines offspring chromatin state and intergenerational obesity. Cell 159 13521364. (doi:10.1016/j.cell.2014.11.005)

Painter RC, Roseboom TJ \& Bleker OP 2005 Prenatal exposure to the Dutch famine and disease in later life: an overview. Reproductive Toxicology 20 345-352. (doi:10.1016/j.reprotox.2005.04.005)

Palm W, Sampaio JL, Brankatschk M, Carvalho M, Mahmoud A, Shevchenko A \& Eaton S 2012 Lipoproteins in Drosophila melanogasterassembly, function, and influence on tissue lipid composition. PLoS Genetics 8 e1002828. (doi:10.1371/journal.pgen.1002828)

Pan DA \& Hardie DG 2002 A homologue of AMP-activated protein kinase in Drosophila melanogaster is sensitive to AMP and is activated by ATP depletion. Biochemical Journal 367 179-186. (doi:10.1042/bj20020703)

Paredes S \& Maggert KA 2009 Ribosomal DNA contributes to global chromatin regulation. PNAS 106 17829-17834. (doi:10.1073/ pnas.0906811106)

Parisi F, Riccardo S, Zola S, Lora C, Grifoni D, Brown LM \& Bellosta P 2013 dMyc expression in the fat body affects DILP2 release and increases the expression of the fat desaturase Desat1 resulting in organismal growth. Developmental Biology 379 64-75. (doi:10.1016/j.ydbio.2013.04.008)

Pasco MY \& Leopold P 2012 High sugar-induced insulin resistance in Drosophila relies on the lipocalin Neural Lazarillo. PLoS ONE 7 e36583. (doi:10.1371/journal.pone.0036583)

Pembrey ME, Bygren LO, Kaati G, Edvinsson S, Northstone K, Sjöström M \& Golding J 2006 Sex-specific, male-line transgenerational responses in humans. European Journal of Human Genetics 14 159-166. (doi:10.1038/sj.ejhg.5201538)
Pospisilik JA, Schramek D, Schnidar H, Cronin SJF, Nehme NT, Zhang X, Knauf C, Cani PD, Aumayr K, Todoric J et al. 2010 Drosophila genomewide obesity screen reveals hedgehog as a determinant of brown versus white adipose cell fate. Cell 140 148-160. (doi:10.1016/j. cell.2009.12.027)

Postic C, Dentin R, Denechaud P-D \& Girard J 2007 ChREBP, a transcriptional regulator of glucose and lipid metabolism. Annual Review of Nutrition 27 179-192. (doi:10.1146/annurev.nutr.27.061406.093618)

Prasad NG, Shakarad M, Rajamani M \& Joshi A 2003 Interaction between the effects of maternal and larval levels of nutrition on pre-adult survival in Drosophila melanogaster. Evolutionary Ecology Research 5 903-911.

Radford EJ, Ito $M$, Shi $H$, Corish JA, Yamazawa K, Isganaitis E, Seisenberger S, Hore TA, Reik W, Erkek S et al. 2014 In utero effects. In utero undernourishment perturbs the adult sperm methylome and intergenerational metabolism. Science 345 1255903. (doi:10.1126/ science.1255903)

Rajan A \& Perrimon N 2012 Drosophila cytokine unpaired 2 regulates physiological homeostasis by remotely controlling insulin secretion. Cell 151 123-137. (doi:10.1016/j.cell.2012.08.019)

Rajan A \& Perrimon N 2013 Of flies and men: insights on organismal metabolism from fruit flies. BMC Biology 11 38. (doi:10.1186/17417007-11-38)

Ravelli AC, van der Meulen JH, Michels RP, Osmond C, Barker DJ, Hales CN \& Bleker OP 1998 Glucose tolerance in adults after prenatal exposure to famine. Lancet 351 173-177. (doi:10.1016/S0140-6736(97)07244-9)

Rayne RC \& O'Shea M 1994 Reconstitution of adipokinetic hormone biosynthesis in vitro indicates steps in prohormone processing. European Journal of Biochemistry 219 781-789. (doi:10.1111/ejb.1994.219. issue-3)

Reiter LT, Potocki L, Chien S, Gribskov M \& Bier E 2001 A systematic analysis of human disease-associated gene sequences in Drosophila melanogaster. Genome Research 11 1114-1125. (doi:10.1101/ gr.169101)

Rhea JM, Wegener C \& Bender M 2010 The proprotein convertase encoded by amontillado (amon) is required in Drosophila corpora cardiaca endocrine cells producing the glucose regulatory hormone AKH. PLoS Genetics 6 e1000967. (doi:10.1371/journal.pgen.1000967)

Rovenko BM, Kubrak OI, Gospodaryov DV, Perkhulyn NV, Yurkevych IS, Sanz A, Lushchak OV \& Lushchak VI 2015a High sucrose consumption promotes obesity whereas its low consumption induces oxidative stress in Drosophila melanogaster. Journal of Insect Physiology 79 42-54. (doi:10.1016/j.jinsphys.2015.05.007)

Rovenko BM, Perkhulyn NV, Gospodaryov DV, Sanz A, Lushchak OV \& Lushchak VI 2015b High consumption of fructose rather than glucose promotes a diet-induced obese phenotype in Drosophila melanogaster. Comparative Biochemistry and Physiology. Part A, Molecular \& Integrative Physiology 180 75-85. (doi:10.1016/j.cbpa.2014.11.008)

Rulifson EJ, Kim SK \& Nusse R 2002 Ablation of insulin-producing neurons in flies: growth and diabetic phenotypes. Science 296 1118-1120. (doi:10.1126/science.1070058)

Sanchez-Martinez A, Luo N, Clemente P, Adan C, Hernandez-Sierra R, Ochoa P, Fernandez-Moreno MA, Kaguni LS \& Garesse R 2006 Modeling human mitochondrial diseases in flies. Biochimica et Biophysica Acta 1757 1190-1198. (doi:10.1016/j.bbabio.2006.05.008)

Schwasinger-Schmidt TE, Kachman SD \& Harshman LG 2012 Evolution of starvation resistance in Drosophila melanogaster: measurement of direct and correlated responses to artificial selection. Journal of Evolutionary Biology 25 378-387. (doi:10.1111/jeb.2012.25.issue-2)

Scott KA, Yamazaki Y, Yamamoto M, Lin Y, Melhorn SJ, Krause EG, Woods SC, Yanagimachi R, Sakai RR \& Tamashiro KLK 2010 Glucose parameters are altered in mouse offspring produced by assisted reproductive technologies and somatic cell nuclear transfer. Biology of Reproduction 83 220-227. (doi:10.1095/biolreprod.109.082826)

Seegmiller AC, Dobrosotskaya I, Goldstein JL, Ho YK, Brown MS \& Rawson RB 2002 The SREBP pathway in Drosophila: regulation by palmitate, not sterols. Developmental Cell 2 229-238. (doi:10.1016/ S1534-5807(01)00119-8)

Sharp GC, Lawlor DA, Richmond RC, Fraser A, Simpkin A, Suderman M, Shihab HA, Lyttleton O, McArdle W, Ring SM et al. 2015 Maternal prepregnancy $\mathrm{BMI}$ and gestational weight gain, offspring DNA methylation and later offspring adiposity: findings from the Avon Longitudinal Study 
of Parents and Children. International Journal of Epidemiology 44 12881304. (doi:10.1093/ije/dyv042)

Sieber MH \& Thummel CS 2009 The DHR96 nuclear receptor controls triacylglycerol homeostasis in Drosophila. Cell Metabolism 10 481-490. (doi:10.1016/j.cmet.2009.10.010)

Slack C, Foley A \& Partridge L 2012 Activation of AMPK by the putative dietary restriction mimetic metformin is insufficient to extend lifespan in Drosophila. PLoS ONE 7 e47699. (doi:10.1371/journal.pone.0047699)

Slaidina M, Delanoue R, Gronke S, Partridge L \& Léopold P 2009 A Drosophila insulin-like peptide promotes growth during nonfeeding states. Developmental Cell 17 874-884. (doi:10.1016/j.devcel.2009.10.009)

Soubry A, Schildkraut JM, Murtha A, Wang F, Huang Z, Bernal A, Kurtzberg J, Jirtle RL, Murphy SK \& Hoyo C 2013 Paternal obesity is associated with IGF2 hypomethylation in newborns: results from a Newborn Epigenetics Study (NEST) cohort. BMC Medical 1129. (doi:10.1186/1741-7015-11-29)

Stanner SA, Bulmer K, Andrès C, Lantseva OE, Borodina V, Poteen VV \& Yudkin JS 1997 Does malnutrition in utero determine diabetes and coronary heart disease in adulthood? Results from the Leningrad siege study, a cross sectional study. BMJ 315 1342-1348. (doi:10.1136/bmj.315.7119.1342)

Staubli F, Jorgensen TJD, Cazzamali G, Williamson M, Lenz C, Sondergaard L, Roepstorff P \& Grimmelikhuijzen CJP 2002 Molecular identification of the insect adipokinetic hormone receptors. PNAS 99 3446-3451. (doi:10.1073/pnas.052556499)

Stenesen D, Suh JM, Seo J, Yu K, Lee K-S, Kim J-S, Min K-J \& Graff JM 2013 Adenosine nucleotide biosynthesis and AMPK regulate adult life span and mediate the longevity benefit of caloric restriction in flies. Cell Metabolism 17 101-112. (doi:10.1016/j.cmet.2012.12.006)

Stothard KJ, Tennant PW, Bell R \& Rankin J 2009 Maternal overweight and obesity and the risk of congenital anomalies: a systematic review and meta-analysis. JAMA 301 636-650. (doi:10.1001/jama.2009.113)

Tatar M, Post S \& Yu K 2014 Nutrient control of Drosophila longevity. Trends in Endocrinology and Metabolism: TEM 25 509-517. (doi:10.1016/j. tem.2014.02.006)

Teixeira L, Rabouille C, Rørth P, Ephrussi A \& Vanzo NF 2003 Drosophila Perilipin/ADRP homologue Lsd2 regulates lipid metabolism. Mechanisms of Development 120 1071-1081. (doi:10.1016/S0925-4773(03)00158-8)

Tennessen JM, Barry WE, Cox J \& Thummel CS 2014 Methods for studying metabolism in Drosophila. Methods 68 105-115. (doi:10.1016/j. ymeth.2014.02.034)

Trinh I \& Boulianne GL 2013 Modeling obesity and its associated disorders in Drosophila. Physiology 28 117-124. (doi:10.1152/ physiol.00025.2012)
Ulgherait M, Rana A, Rera M, Graniel J \& Walker DW 2014 AMPK modulates tissue and organismal aging in a non-cell-autonomous manner. Cell Reports 8 1767-1780. (doi:10.1016/j.celrep.2014.08.006)

Vahratian A 2009 Prevalence of overweight and obesity among women of childbearing age: results from the 2002 National Survey of Family Growth. Maternal and Child Health Journal 13 268-273. (doi:10.1007/ s10995-008-0340-6)

Valtonen TM, Kangassalo K, Polkki M \& Rantala MJ 2012 Transgenerational effects of parental larval diet on offspring development time, adult body size and pathogen resistance in Drosophila melanogaster. PLOS ONE 7 e31611. (doi:10.1371/journal.pone.0031611)

Van der Horst DJ 2003 Insect adipokinetic hormones: release and integration of flight energy metabolism. Comparative Biochemistry and Physiology. Part B, Biochemistry \& Molecular Biology 136 217-226.

Vienna Drosophila RNAi Center 2015 VDRC transgenic RNAi libraries.

Vijendravarma RK, Narasimha S \& Kawecki TJ 2010 Effects of parental larval diet on egg size and offspring traits in Drosophila. Biology Letters 6 238-241. (doi:10.1098/rsbl.2009.0754)

Vucetic Z, Kimmel J, Totoki K, Hollenbeck E \& Reyes TM 2010 Maternal high-fat diet alters methylation and gene expression of dopamine and opioid-related genes. Endocrinology 151 4756-4764. (doi:10.1210/ en.2010-0505)

Wu LL, Dunning KR, Yang X, Russell DL, Lane M, Norman RJ \& Robker RL 2010 High-fat diet causes lipotoxicity responses in cumulus-oocyte complexes and decreased fertilization rates. Endocrinology 1515438 5445. (doi:10.1210/en.2010-0551)

Wu LL, Russell DL, Wong SL, Chen M, Tsai T-SS, St John JC, Norman RJ, Febbraio MA, Carroll J \& Robker RL 2015 Mitochondrial dysfunction in oocytes of obese mothers: transmission to offspring and reversal by pharmacological endoplasmic reticulum stress inhibitors. Development 142 681-691. (doi:10.1242/dev.114850)

Zhang H, Stallock JP, Ng JC, Reinhard C \& Neufeld TP 2000 Regulation of cellular growth by the Drosophila target of rapamycin dTOR. Genes \& Development 14 2712-2724.

Received 16 December 2015

First Decision 20 January 2016

Revised manuscript received 26 April 2016

Accepted 17 May 2016 